\title{
THE PARTICIPATION OF TRANSGENDERS IN SPORT. RIGHT TO EQUALITY AND EQUAL OPPORTUNITIES IN SPORT
}

\section{UDZIAŁ OSÓB TRANSPŁCIOWYCH W SPORCIE. PRAWO DO RÓWNOŚCI A RÓWNOŚĆ SZANS W SPORCIE}

\begin{abstract}
A characteristic feature of sport since ancient times is competition and the will to win. The basic criteria for the division of competition are goal, discipline and gender. In the last three decades the gender division of athletes has been the most controversial. It is caused by the increasing participation of transgender people in sports competitions, especially in women's disciplines. The aim of the study is to summarize all the arguments used in the discussion on the participation of transgender people in sports competitions. Will the inclusion of transgender people in women's sports not cause the twilight of women's sports? The research hypothesis is the statement that it is necessary to search for a solution for the willingness of transgender people's participation in sports competitions. The unquestionable right of these people to train sport must be however confronted with the right to fair competition based on equal opportunities. The study uses the method of analyzing specific cases, the analysis of international law, sports organization law and Polish law. Last but not least, elements of the legal-historical method is used to present the perspective of the development of public discussion and legal regulations concerning the participation of transgender people in professional sport. The result of the work is the presentation of specific solutions to this issue.
\end{abstract}




\section{STRESZCZENIE}

Cechami charakterystycznymi sportu od czasów antycznych są rywalizacja i wola zwycięstwa. Podstawowymi kryteriami podziału rywalizujących ze sobą sportowców są cel, dyscypliny i płeć. W ostatnich trzech dekadach najwięcej kontrowersji budzi podział sportowców ze względu na płeć. Przyczyną powyższego jest coraz częstszy udział osób transpłciowych w zawodach sportowych, zwłaszcza w dyscyplinach kobiecych. Celem opracowania jest zestawienie wszelkich argumentów używanych w dyskusji nad udziałem osób transpłciowych w zawodach sportowych. Czy włączenie osób transpłciowych do kobiecych sportów nie wpłynie na wywołanie zjawiska zmierzchu dotychczasowego sportu kobiecego? Hipotezę badawczą stanowi twierdzenie, iż konieczne jest poszukiwanie rozwiązania kwestii udziału osób transpłciowych w zawodach sportowych. Niekwestionowane prawo tych osób do uprawiania sportu musi jednak być skonfrontowane $\mathrm{z}$ prawem do sprawiedliwej rywalizacji opartej na równości szans. W pracy została użyta metoda analizy konkretnych przypadków, analizy przepisów prawa międzynarodowego, prawa organizacji sportowych oraz prawa polskiego. W jej zakończeniu zastosowane są elementy metody historycznoprawnej, dzięki której została ukazana perspektywa rozwoju dyskusji i regulacji prawnych dotyczących udziału osób transpłciowych w sporcie zawodowym. Efektem pracy jest konkretne rozwiązania tej kwestii.

KEYWORDS: transgender, sports law, competition, human rights, equal opportunities.

SŁOWA KLUCzowe: transpłciowość, prawo sportowe, współzawodnictwo, prawa człowieka, równość szans.

\section{WPROWADZENIE}

Od kilku dekad toczy się dyskusja nad udziałem osób transpłciowych w sporcie. Jeszcze do połowy XX w. sportowcy byli dzieleni według dyscyplin i płci. Jedynak w historii sportu można wskazać wiele przypadków, gdy organizatorzy imprez sportowych, a także kibice mieli wątpliwości co do płci sportowca, a tym samym i co do zasad równej konkurencji. Podłożem powyższych wątpliwości jest coraz bardziej dostrzegana dominacja osób transpłciowych w sportach żeńskich, zwłaszcza w dyscyplinach indywidualnych.

Celem pracy jest analiza aktów prawa międzynarodowego, zwłaszcza prawa sportowego, oraz przedstawienie problemu na podstawie wybranego kazusu. W dalszej kolejności celem opracowania jest próba wyważenia prawa czło- 
wieka do sportu z prawem do uczciwego i sprawiedliwego współzawodnictwa w sporcie. Stąd rodzi się pytanie, czy udział osób transpłciowych głównie w sportach kobiecych i ich dominacja nie spowoduje utraty zaufania do sprawiedliwego współzawodnictwa, co stanowi fundament rywalizacji sportowej od czasów antycznych. Stąd hipotezą badawczą jest twierdzenie, iż możliwe jest znalezienie rozwiązania, które pozwoli osobom transpłciowym na udział w zawodach sportowych z jednoczesnym zachowaniem obecnego kształtu sportów kobiecych opartego na rywalizacji opartej na zasadzie równych szans.

\section{PODSTAWY PRAWNE PRAWA KAŻDEgo CZŁOWIEKA DO UPRAWIANIA SPORTU}

Bezpośrednią przyczyną podjęcia się analizy zjawiska sportowców transpłciowych jest jedno z pierwszych rozporządzeń podpisane przez nowego prezydenta Stanów Zjednoczonych Ameryki Północnej Joe Bidena w dniu inauguracji jego prezydentury. Chodzi o zarządzenie Executive Order on Preventing and Combating Discrimination on the Basis of Gender Identity or Sexual Orientation z 20 stycznia 2021 r. Ostanie zdanie akapitu $1 \mathrm{w}$ sec. 1 stanowi, że wszyscy ludzie powinni być równo traktowani wobec prawa bez względu na ich tożsamość płciową czy orientację seksualną, co odnosi się do wszystkich dziedzin życia, w tym do sportu. W przedmiotowym rozporządzeniu zostały przywołane wcześniejsze regulacje prawe, zawarte m.in. w tytule VII Civil Rights Act z 1964 r., w tytule IX poprawki z 1972 r. do art. 20 United States Code oraz w sec. 412 Immigration and Nationality Act, będącej poprawką do art. 8 United States Code (Bennett, 1966, s 127-136). Niewątpliwą nowością niniejszego rozporządzenia prezydenta J. Bidena jest jednoznaczne uznanie podziału ludzi ze względu na płeć za czynnik dyskryminujący. Takie zdecydowane stanowisko prezydenta Stanów Zjednoczonych Ameryki Północnej znalazło odzwierciedlenie w mediach, m.in. w odniesieniu do dalszego losu sportów kobiecych w tradycyjnym ich rozumieniu.

W podstawowych aktach prawa międzynarodowego dotyczących praw człowieka nie występują przepisy prawne, które pozwoliłyby stwierdzić, że odniesienie się do płci człowieka jako elementu określającego jego status społeczny czy stan cywilny może być uznane za kryterium dyskryminujące. W art. 2 
Powszechnej deklaracji praw człowieka zapisano, że każdy człowiek jest uprawniony do korzystania ze wszystkich praw i wolności, bez względu m.in. na płeć. Według Marka Piechowiaka katalog cech człowieka określonych w tym artykule jest otwarty. Świadczy o tym końcowe stwierdzenie użyte w tekście art. 2, a mianowicie iż nie jest dopuszczalna dyskryminacja człowieka z powodu jakichkolwiek innych różnic (ang. other status). Zatem z punktu widzenia praw człowieka nie można nikomu odmówić korzystania z praw i wolności (Piechowiak, 2009, s. 177-193). Niewątpliwie uprawianie sportu jest prawem każdego człowieka i nie można go tego prawa pozbawić, nawet ze względu na niemożliwość jednoznacznego określenia jego płci (jako żeńską lub męską). Problem ów jest istotny, gdyż w ostatnich latach coraz więcej osób transpłciowych uprawia sport zawodowo (Jones, 2017, s. 701 i nast.).

Nie stanowi zatem problemu fakt uprawnia sportu zawodowego przez osoby transpłciowe, lecz kwestią fundamentalną jest wypracowanie takich reguł, które zagwarantowałaby obiektywizację wyników sportowych, a tym samym i współzawodnictwa. Niewątpliwie każdy sportowiec ma prawo do rywalizacji. Jest to jego prawo jako prawo człowieka i jako prawo podmiotowe chronione przepisami prawa pozytywnego. Jednak prawo do rywalizacji czy współzawodnictwa ma sens wówczas, gdy jest ono oparte na zasadzie równych szans.

\section{Kryteria PODZIAEÓW W SPORCIE}

Sport jest jedną z tych dziedzin aktywności człowieka, w których dokonuje się różnego rodzaju podziałów i klasyfikacji. Do najważniejszych kryteriów podziałów w sporcie należy zaliczyć cel aktywności, rodzaj dyscypliny i płeć zawodników. Kryterium celu pozwala podzielić aktywność sportową na czysto rekreacyjną, czyli amatorską, oraz na zawodową, uprawianą w sposób profesjonalny. To właśnie w tym obszarze sportu znaczenie mają dwa kolejne kryteria podziału, tj. ze względu na dyscyplinę i płeć. W ramach dyscyplin występują sporty indywidualne i zespołowe. Ze względu na płeć wyróżnia się sporty męskie i żeńskie. Podziały te czasami nakładają się na siebie w dyscyplinach zespołowych, np. debel mieszany w tenisie ziemnym. 
Zasadniczym kryterium podziału sportowców w ramach dyscyplin sportowych jest płeć. Podstawą przyjęcia tego kryterium podziału są istniejące różnice fizjologiczne między osobami różnej płci i wynikające stąd przekonanie o różnej wydolności fizycznej mężczyzn i kobiet. Zgodnie z tym punktem widzenia powszechnie uważa się, że wspólna rywalizacja osób obu płci nie byłaby obiektywna i sprawiedliwa. Dalszym ważkim argumentem dla utrzymania tego podziału jest kwestia zachowania intymności i nietykalności osobistej - istotna zwłaszcza w odniesieniu do kobiet.

Współczesny sport zawodowy jest dobrze zorganizowany. Poszczególne grupy dyscyplin posiadają własne federacje międzynarodowe, np. $\mathrm{MKOl}$, FIFA, czy krajowe, jak np. PKO oraz PZPN. O istnieniu i organizacji zawodów w poszczególnych dyscyplinach decydują zatem już nie sami sportowcy, lecz właśnie profesjonalne organizacje sportowe, które posługują się własnym prawem. System prawny międzynarodowych federacji sportowych najczęściej ma pierwszeństwo przed prawem krajowym (Fundowicz, 2013, s. 64 i nast.).

Od kilku dekad najbardziej problematycznym kryterium podziału w sporcie jest płeć. Dotychczasowe tendencje działań organizacji czy związków sportowych, ale też i rządów poszczególnych państw, zmierzały do zagwarantowania równouprawnienia mężczyzn i kobiet w kontekście udziału w zawodach sportowych. Kładziono nacisk m.in. na wyrównanie wysokości jakichkolwiek gratyfikacji czy wynagrodzeń w danej dyscyplinie niezależnie od płci (Jakubowska, 2012, s. 191-203). Przykładem jest dość zwycięska walka kobiet o równe premie dla triumfatorek i triumfatorów turniejów w tenisie zmiennym (a zatem o takie samo traktowanie bez względu na płeć).

Postulowana równość płci (ang. equality) zakłada zapewnienie pełnego dostępu do szans i korzyści. Takie rozwiązania znajdują odzwierciadlenie w aktach prawnych międzynarodowych, w prawie wewnętrznym międzynarodowych organizacji sportowych i w prawie wewnętrznym krajowych organizacji sportowych.

Na tym tle rodzi się fundamentalne pytanie o dopuszczenie osób transpłciowych do zawodów sportowych niezależnie od określenia płci danej osoby. Pytanie to nabiera jeszcze większego znaczenia w kontekście faktu, że zasadniczo osoby transpłciowe występują w grupie sportowców płci żeńskiej. Niezwykle rzadko osoby takie występują w grupie zawodników mężczyzn. 
Fakt, że osoby transpłciowe występują głównie w grupie sportowców kobiet rodzi kolejne pytanie, a mianowicie w jaki sposób rozwiązać trudności w określaniu obiektywnych, czyli sprawiedliwych, opartych na tych samych przesłankach, nie zaś ideologicznych, reguł zawodów sportowych i systemów określania zwycięzcy. Czy przyzwolenie na nieograniczony udział osób transpłciowych w zawodach sportowych nie spowoduje utraty przez kobiety motywacji do uprawiania sportu, które to nie będą przekonane do stosowania równych reguł, a zatem do równych szans we współzawodnictwie? Zjawisko to może wystąpić zwłaszcza w dyscyplinach indywidualnych.

\section{PrzeŁamanie stereotypowego Podziału SPORTOWCÓW ZE WZGLĘDU NA PEEĆ}

Współcześnie prowadzi się coraz więcej badań i opracowań naukowych nad zasadnością podziału sportowców ze względu na płeć (McDonagh, Pappano, 2007, s. 39 i nast.). Stopniowe przełamanie podziału sportowców ze względu na płeć można było odnotować już w początkach XX w., przede wszystkim w tenisie ziemnym, kiedy zaczęto organizować zawody mieszane - mixed-sex sports. Dość wcześnie, bowiem już podczas igrzysk olimpijskich w 1912 r. w Sztokholmie, jedną z dyscyplin była rywalizacja w grze mieszanej, w hali, w tenisie zmiennym. Z kolej w 1913 r. wprowadzono do turnieju tenisowego na Wimbledonie odrębną konkurencję debla mieszanego (Jans, Moska, 2011, s. 79).

W niektórych dyscyplinach sportowych, tam gdzie kwestia wydolności fizycznej nie odgrywała większej roli, zwłaszcza w sportach ocenianych artystycznie, takich jak łyżwiarstwo figurowe czy gimnastyka artystyczna, zespoły mieszane występowały już w połowie XX w. Są też dyscypliny, w których od początku ich uprawiania nie stosowano podziału zawodników ze względu na płeć, np. snooker.

Obecnie MKOl wprowadza do wielu dyscyplin zespołowych wspólną rywalizację przedstawicieli obu płci z zachowaniem równego parytetu. I tak na lekkoatletycznych mistrzostwach świata w 2017 r. zespoły mieszane wystąpiły w sztafecie 4 x $400 \mathrm{~m}$. Podobne zasady zaczynają obowiązywać w innych 
dyscyplinach zespołowych lekkoatletycznych czy w zespołowych sportach zimowych. W wielu dyscyplinach podczas przesuniętej na 2021 r. olimpiady w Tokio rywalizacja będzie opierała się na koncepcji mixed-sex sports.

Znacznie trudniej jest wprowadzić rywalizację między płciami w dyscyplinach indywidualnych. W tym przypadku odnotowuje się organizowanie zawodów sportowych dla kobiet w dyscyplinach dotychczas uważanych za typowo męskie, takich jak skoki narciarskie czy boks. W tym przypadku raczej trudno będzie znaleźć obiektywne kryterium równoważące dysproporcje między płciami, które wynikają z uwarunkowań fizjonomicznych człowieka (Pizzolati, Sterchele, 2016, s. 1267 i nast.).

W wielu centrach sportowych czy instytutach badawczych prowadzone są badania medyczne nad somatyczną i psychiczną stroną osób transpłciowych uprawiających sport zawodowo. Przykładem tego mogą być badania prowadzone na pływakach w Holandii. Badania te mają na celu również stwierdzenie przewagi fizycznej takich osób nad innymi kobietami startującymi w dyscyplinach indywidualnych (Elling-Machartzki, 2017, s. 256-268).

W Wielkiej Brytanii z kolei w latach 2007-2011 przeprowadzano badania nad możliwością organizowania integracji płci w sztukach walk i sportach walk. Wyniki tych badań pokazują, że możliwe jest prowadzenie zintegrowanych walk, co może doprowadzić do odejścia od podziału zawodników ze względu na płeć. Trudno jednak jest jednoznacznie pozytywnie oceniać wyniki tych badań, nie znając próby badawczej ani metodologii prowadzonych badań (Channon, 2014, s. 587-605).

Efektem tych badań jest wniosek, że nie można jednoznacznie naukowo potwierdzić przewagi w zakresie wydolności fizycznej osób transpłciowych nad innymi kobietami, które nie wykazują takich cech. Nie można też jednoznacznie stwierdzić, że udział osób transpłciowych w konkurencjach kobiecych jednoznacznie przekreślałby obiektywne współzawodnictwo. Te wątpliwości wynikające z prowadzonych badań naukowych nie negują dość powszechnego poglądu, że w praktyce większa wydolność fizyczna osób transpłciowych niż innych kobiet jest widoczna dla wszystkich. To z kolei kreuje pytanie o równość szans i sprawiedliwe współzawodnictwo. Zatem jakie kryteria winny być brane pod uwagę podczas zawodów sportowych - rodzaj treningów, systematyczność, wytrwałość czy też większa wydolność 
fizyczna wynikająca z wysokiego poziomu testosteronu? Oczywiście należy mieć na uwadze fakt, że również wśród kobiet, które nie wykazują cech transpłciowości, występują niekiedy znaczne różnice w budowie fizycznej, np. siostry Williams słyną z potężnej budowy ciała i wyjątkowej wydolności fizycznej, a jednak nigdy nie wysuwano wobec nich argumentów nierównego czy niesprawiedliwego współzawodnictwa.

\section{ZMIANY W PRAWIE SPORTOWYM}

Prowadzona dyskusja naukowa, polityczna, medialna, zwłaszcza w Internecie, czy społeczna nad udziałem osób transpłciowych w rywalizacji sportowej prowadzi do powolnych konkretnych zmian w ustawodawstwie sportowym, zwłaszcza w prawie międzynarodowym organizacji sportowych. W art. 4 w motywie 1 Europejskiej Karty Sportu z 25 września 1992 r. wprowadzono zasadę, iż zakazuje się w sporcie jakiejkolwiek dyskryminacji ze względu m.in. na płeć, orientację seksualną, kolor skóry, język, religię, politykę, narodowość, przynależność do stowarzyszeń mniejszości narodowych. Uzupełnieniem Karty jest Kodeks Etyki Sportowej również z 1992 r. W motywie 5 Kodeksu stwierdzono, że głównym przesłaniem etyki sportowej musi być równy udział kobiet, dziewczynek, mężczyzn i chłopców w indywidualnych czy zespołowych zawodach, bez jakiejkolwiek dyskryminacji ze względu na płeć.

W rekomendacji CM/Rec(2010)5 Komitetu Ministrów dla Państw Członkowskich w zakresie środków zwalczania dyskryminacji opartej na orientacji seksualnej lub tożsamości płciowej w motywie 40 stwierdzono, że aktywność sportowa powinna być otwarta na każdego człowieka bez względu na orientację seksualną czy płeć. Wszelkie działania dyskryminacyjne winny spotkać się z potępieniem i podlegać karze. Ponadto postuluje się prowadzenie działalności prewencyjnej poprzez edukację i dialog.

Peambuła rekomendacji CM/Rec(2010)5 Komitetu Ministrów dla Państw Członkowskich w zakresie środków zwalczania dyskryminacji opartej na orientacji seksualnej lub tożsamości płciowej zawiera postanowienie, że nie można usprawiedliwiać jakiekolwiek formy dyskryminacji ze względu na argument dominującej kultury. Dotyczy to także sfery sportu. 
W rekomendacji parlamentarnej 1635 (2003) - Geje i lesbijki w sporcie z 25 listopada 2003 r. przywołane zostały wcześniejsze dokumenty zakazujące jakiejkolwiek dyskryminacji sportowców ze względu na rasę, przynależność polityczną czy orientację seksualną (motyw 2), m.in. Karta Olimpijska oraz Protokół Nr 12 art. 1 Europejskiej konwencji praw człowieka i podstawowych wolności. W rekomendacji 1635 w motywie 7 III pojawia się zakaz dyskryminacji ze względu na płeć. Oznacza to, że nie można odmówić udziału w zawodach czy zajęciach sportowych osobie, która nie ma jednoznacznych cech płci żeńskiej lub męskiej.

Jednak nie we wszystkich organizacjach sportowych występuje zjawisko odchodzenia od podziału zawodników ze względu na płeć. W sec. 5 w motywie 29 Kodeksu etycznego FIFA (FIFA Code of Ethics 2020 edtition) postanowiono, że w zawodach piłki nożnej zakazane jest, aby zawodnicy dopuszczali się manipulacji zawodami czy współzawodnictwem. Jak z tej perspektywy ocenić czy zakwalifikować występowanie w drużynie męskiej osoby, która posiada wyraźne cechy męskie, ale deklaruje się jako kobieta? Czy w tym przypadku można mówić o równości szans? Czy nie jest to forma manipulacji współzawodnictwem sportowym? O podziale zawodników piłki nożnej ze względu na płeć jeszcze dobitniej mówi statut FIFA. W jego pkt 6.1 została uregulowana kwestia rejestracji piłkarzy. Federacje krajowe mają prawo same określić okres takich rejestracji każdego roku zarówno dla mężczyzn, jak i dla kobiet. Takie sformułowanie oznacza, że dla FIFA podział piłkarzy z względu na płeć nadal ma istotne znaczenie. Podobnie jest w innych organizacjach sportowych.

\section{KAZUS CASTER SEMENYI}

Ostatnio media nagłaśniały kazus Caster Semenyi, zawodniczki z RPA, która od 2011 r. odniosła liczne sukcesy sportowe w biegach średniodystansowych (Wach, 2005, s. 143). W 2019 r. na podstawie wyroku Sportowego Sądu Arbitrażowego w Lozannie (Court of Arbitration for Sport) zawodniczka nie została dopuszczona do udziału w Lekkoatletycznych Mistrzostwach Świata odbywających się w dniach 27 września-6 października 2019 r. w Doha w Katarze. Caster Semenya zaskarżyła do tego samego sądu ważność regulaminu kwalifikacji kobiet (Eligibility Regulations for the Female Classification). 
Skład sędziowski rozpatrujący skargę sportsmenki 19 lipca 2018 r. stwierdził, że przepisy zawarte $\mathrm{w}$ regulaminie są potencjalnie dyskryminujące, jednak taka dyskryminacja jest niezbędnym, rozsądnym i proporcjonalnym środkiem do osiągnięcia zamierzonego celu, jakim jest zapewnienie uczciwej rywalizacji kobiet w lekkiej atletyce (Communication: Caster Semenya conteste le Reglement de l'IAAF Regissant la Qualification dans la Categorie Feminine devantlLe Tribunal Arbitral du Sport).

Jednak w decyzji w sprawie Caster Semenyi, Athletics South Africa (Asa) vs Lassociation Internationale Des Federations D’athletisme z dnia 1 maja 2019 r. Sportowy Sąd Arbitrażowy wyraził wątpliwość, czy stosowanie kryterium poziomu testosteronu w organizmie kobiety jest właściwe. Ustalona granica jego poziomu może zostać chwilowo i mimowolnie przekroczona. Sąd też nie podziela stanowiska, według którego osoby transpłciowe mają przewagę fizyczną nad innymi sportsmenkami, zwłaszcza w biegach średniodystansowych. Decyzja ta została podjęta większością głosów składu sędziowskiego.

\section{RYWALIZACJA CZY WSPÓEZAWODNICTWO W SPORCIE}

Terminem „sport” obejmuje się różnego rodzaju aktywności nie tylko fizyczne, ale także intelektualne. Zgodnie z art. 2 ust 1 Ustawy z dnia 25 czerwca 2010 r. o sporcie (Dz.U. z 2020 r. poz. 1133) sportem można nazwać aktywności doraźne i zorganizowane, które służą poprawieniu kondycji fizycznej i psychicznej oraz prowadzą do osiągnięcia wyników sportowych na wszelkich poziomach. Zaś według art. 2 ust. 1 tej ustawy za sport uznaje się współzawodnictwo oparte na aktywności intelektualnej, które zmierza do osiągnięcia wyniku sportowego (Ulijasz, 2019, s. 23).

Tak szeroko rozumiana przez polskiego ustawodawcę definicja sportu koresponduje $\mathrm{z}$ definicjami znajdującymi się $\mathrm{w}$ aktach prawa międzynarodowego, zwłaszcza w Europejskiej Karcie Sportu i w Białej księdze na temat sportu (White Paper on Sport - Com (2007) 391 final), wydanej przez Komisję Europejską.

Nie budzi doktrynalnych czy ustawowych wątpliwości oddzielenie uprawiania sportu zawodowo od sportu uprawianego w celach rekreacyjnych 
czy zdrowotnych. Istotnym elementem zawodowego uprawiania sportu jest wola walki i wygrania zawodów, zdobycia głównej nagrody. Zasadnicznym elementem sportu zawodowego jest zatem wola walki, rywalizacja z innymi uczestnikami zawodów. Same zawody są poprzedzone długim i wymagającym procesem treningu odbywanego często pod nadzorem fachowców, m.in. lekarzy, fizjoterapeutów czy psychologów. Ostatecznie podczas zawodów sportowych wygrywa najlepszy. Rywalizacji sportowej przyznaje się również funkcje edukacyjne.

W doktrynie można spotkać trzy koncepcje celu uprawnia sportu. Zwolennicy pierwszej z nich postrzegają sport wyłącznie jako walkę z przeciwnikami, czyli rywalizację o wygraną (interpretacja agonistyczna sportu). Celem sportu nie jest jednak zniszczenie przeciwnika, lecz walka oparta na zachowaniu reguł, równości szans i przestrzeganiu zasady fair play. Według drugiej koncepcji sport jest formą zabawy. A zatem sport nie zawiera elementu przymusu, jest działaniem wolnym i odświętnym. Według trzeciej koncepcji sport jest formą edukacji zmierzającej do wykształcenia pewnych cech potrzebnych człowiekowi w życiu społecznym, takich jak: wytrwałość, uczciwość, solidarność czy samodyscyplina (Judycki, 2008, s. 2-3).

Współcześnie zaś, zamiast takich terminów jak „rywalizacja” czy „konkurencja”, w sporcie w języku oficjalnym, w tym również w tekstach normatywnych, nie używa się terminu „rywalizacja”, lecz „współzawodnictwo”, które to winno być otwarte i uczciwe. Zmiana terminu nie zmienia jednak podstawowej funkcji sportu zawodowego, jaką jest zwycięstwo. W każdym rodzaju sportu ważna jest motywacja. Według motywu 2.2 Białej Księgi na temat sportu w sporcie zawodowym istotne znaczenie ma wola współzawodnictwa, a w konsekwencji chęć wygrania zawodów.

W Kodeksie dobrego zarządzania dla polskich związków sportowych kilkanaście razy w tekście dokumentu powraca się do tematu współzawodnictwa sportowego. Według tego kodeksu gwarantem uczciwego współzawodnictwa są związki sportowe, które ustalają i realizują reguły sportowe rządzące współzawodnictwem. Jednak stosunkowo mało miejsca poświęcono zasadom czy regułom współzawodnictwa uwzględniające również osoby transpłciowe. 


\section{Podsumowanie}

Bezspornym faktem jest coraz większy udział osób transpłciowych w sporcie zawodowym. Nie można negować niezbywalnego prawa tych osób do uprawiania sportu i uczestnictwa w zawodach sportowych. Najczęściej występują one w sportach żeńskich. Stąd przedmiotem szerokiej dyskusji oraz wielu wątpliwości jest kwestia wydolności fizycznej osób transpłciowych, a w konsekwencji rodzi się pytanie o zasady organizacji współzawodnictwa czy rywalizacji w sporcie, które gwarantowałby fundamentalną zasadę równości szans.

Prowadzone w różnych krajach badania naukowe koncentrują się głównie na pomiarze wydolności fizycznej osób transpłciowych. Nie wynikają $\mathrm{z}$ nich jednoznaczne wnioski. Stąd też w prawie sportowym jak dotąd nie ma jednoznacznych regulacji prawnych w tym zakresie. Przykładem jest kazus Caster Semenyi, sportsmenki z RPA, rozstrzygany przez Sportowy Sąd Arbitrażowy w Lozannie. Sąd wykluczył sportsmenkę z udziału w mistrzostwach świata w lekkoatletyce, nie dając jednocześnie żadnego konkretnego rozwiązania w sprawie.

Biorąc pod uwagę brak jakichkolwiek roszczeń normatywnych czy sądowych w kwestiach udziału osób transpłciowych w zawodach sportowych oraz uwzględniając dość różne poglądy doktryny i powszechne przekonania, wydaje mi się konieczne zaproponowanie konkretnego rozwiązania, które wywoła życiową i merytoryczną dyskusję doktrynalną (Bojarska, Kłonkowska, 2014, s. 64 i nast.).

Punktem wyjścia do zaproponowanego przez mnie rozwiązania jest fakt, że są organizowane zawody sportowe dla szczególnych grup ludzi, np. igrzyska czy mistrzostwa paraolimpijskie dla osób niepełnosprawnych. Wyodrębnienie tych grup sportowców nie stanowi podstawy do sformułowania zarzutu o jakiejkolwiek formie dyskryminacji. Co więcej, powszechnie uznaje się, organizowanie aktywności sportowej, a także współzawodnictwa sportowego dla osób z określonymi dysfunkcjami fizycznymi jest czymś niezwykle pozytywnym. W ten sposób stwarza się im szanse rywalizacji i realizacji swoich motywacji, celów życiowych i ambicji.

Moim zdaniem należałoby wydzielić kategorie sportowe dla osób transpłciowych. Wyodrębnienie tej grupy nie byłoby przejawem dyskryminacji ze względu na płeć, podobnie jak to jest $\mathrm{z}$ osobami mającymi różne dysfunkcje 
fizyczne. Tym samym zostałaby zachowana podstawowa zasada w sporcie, a mianowicie równość szans we współzawodnictwie przy uwzględnieniu tych samych kryteriów rywalizacji. Co więcej, według mnie należałoby organizować wspólne zawody sportowe dla wszystkich rodzajów zawodników, nie zaś tworzyć odrębne. W mojej opinii odrębna organizacja paraolimpiad jest przejawem dyskryminacji tej grupy sportowców.

\section{Bibliografia}

Bennett, M.T. (1966). The immigration and nationality (McCarran-Walter) Act of 1952, as Amended to 1965, „The Annals of the American Academy of Political and Social Science", No. 367/1, s. 127-136.

Bojarska, K., Kłonkowska, A.M. (2014). TRANSgresja płci, TRANZycja ciała, TRANSwersja tożsamości. Czym jest TRANSpłciowość. W: A.M. Kłonkowska, K. Bojarska K. (red.), Psychospołeczne, prawne i medyczne aspekty transpłciowości, Gdańsk: Wydawnictwo Uniwersytetu Gdańskiego, s. 64-82.

Channon, A. (2014). Towards the "undoing" of gender in mixed-sex martial arts and combat sports, „Societies”, No. 4/4, s. 587-605.

Elling-Machartzki, A. (2017). Extraordinary body-self narratives: Sport and physical activity in the lives of transgender people, „Leisure Studies”, No. 36/2, s. 256-268.

Fundowicz, S. (2013). Prawo sportowe, Warszawa: Wolters Kluwer Polska. ISBN 9788326442384.

Jakubowska, H. (2012). Zasady wynagradzania w sporcie w kontekście idei sprawiedliwości i równości płci, „Ruch Prawniczy, Ekonomiczny i Socjologiczny”, nr 74, s. 191-203. ISSN 0035-9629.

Jans, W., Moska, W. (2011). Tenis na igrzyskach olimpijskich w latach 1896-2008, „Rocznik Naukowy Akademii Wychowania Fizycznego i Sportu im. Jędrzeja Śniadeckiego w Gdańsku", s. 77-87. ISSN 1730-7953.

Jones, B.A., et al. (2017). Sport and transgender people: a systematic review of the literature relating to sport participation and competitive sport policies, „Sports Medicine", No. 47/4, s. 701-716.

Judycki, S. (2008). Filozofia sportu, Lublin: KUL, s. 2-3(1-8), http://www. kul. pl/ files/57/wydzial/judycki/filozofia_sportu (dostęp: 10.02.2021).

Kopczyk, R. (2013). Zakaz dyskryminacji w sporcie $w$ prawie Unii Europejskiej (stan prawny na 1 stycznia 2013 r.), Warszawa: Wolters Kluwer Polska. ISBN 9788326441592. 
McDonagh, E., Pappano, L. (2007). Playing with the boys: Why separate is not equal in sports, Oxford: Oxford University Press. ISBN 9780195386776.

Piechowiak, M. (2009). Powszechność - między uniformizacja a relatywizmem. Wokół metaaksjologicznych założeń Powszechnej Deklaracji Praw Człowieka. W: T. Jasdudowicz, M. Balcerzak, J. Kapelańska-Pręgowska, Współczesne problemy praw człowieka i międzynarodowego prawa humanitarnego, Toruń: Towarzystwo Naukowe Organizacji i Kierownictwa „Dom Organizatora”, s. 177-193. ISBN 9788372854841 .

Pizzolati, M., Sterchele, D. (2016). Mixed-sex in sport for development: a pragmatic and symbolic device. The case of touch rugby for forced migrants in Rome, „Sport in Society", No. 19(8-9), s. 1267-1288. ISSN 1743-0445.

Ulijasz, B. (2019). Wykonywanie i organizowanie sportu w Polsce. Studium administracyjno-prawne, Toruń: Wydawnictwo Adam Marszałek. ISBN 9788366220669.

Wach, A. (2005). Alternatywne formy rozwiązywania sporów sądowych, Warszawa: LIBER. ISBN 8372061122.

\section{Akty prawne}

Biała Księga na temat sportu (White Paper on sport - Com (2007) 391 final).

Europejska Karta Sportu (European Sports Charter), przyjęta jako Rekomendacja No. R (92) REV Rady Europy.

Europejska konwencja praw człowieka i podstawowych wolności, Protokół Nr 12, art. 1.

Kodeks dobrego zarządzania dla polskich związków sportowych, nazwany również Uczciwość w sporcie i skuteczność w działaniu, przygotowany przez nieistniejące już Ministerstwo Sportu i Turystyki, file://Users/Bronek/Downloads/Kodeks_Dobrego_Zarzadzania_dla_Polskich_Zwiazkow_Sportowych.pdf (dostęp: 8.02.2021).

Kodeks etyczny FIFA (FIFA Code of Ethics 2020 edtition), https://resources.fifa. $\mathrm{com} /$ image/upload/fifa-code-of-ethics-2020.pdf?cloudid=upxpc0qzxqdgipiiejuj (dostęp: 10.02.2021).

Ustawa z dnia 3 grudnia 2010 r. o wdrożeniu niektórych przepisów Unii Europejskiej w zakresie równego traktowania (Dz.U. z 2010 r. nr 254, poz. 1700). 